\title{
Biodegradable coatings on the postharvest of blackberry stored under refrigeration ${ }^{1}$
}

\author{
Revestimentos biodegradáveis na pós-colheita de amora-preta armazenada sob \\ refrigeração
}

\author{
Dalany Menezes Oliveira² ${ }^{2}$ Cassia Ines Lourenzi Franco Rosa², Angela Kwiatkowski² e Edmar Clemente ${ }^{3 *}$
}

\begin{abstract}
Blackberry is a notable fruit due to bioactive compounds. However it has a fragile structure, which reduces the consumption in natura. The aim of this study was to evaluate the physical and chemical quality of the cv. Tupy blackberry fruits, produced in an organic system, and coated with emulsions based on cassava starch and water kefir grains stored under refrigeration. The fruits were divided into three groups: a control (T1) and two treatments with coatings. The coatings used were: cassava starch solution $2.5 \%$ (T2); water kefir grains at 20\% (T3). The fruits of the three treatments were stored at $10 \pm 2{ }^{\circ} \mathrm{C}$ and $\mathrm{RH} 85 \pm 3 \%$, and were evaluated every three days for 12 days period. It was determined: weight loss, firmness, $\mathrm{pH}$, titratable acid, soluble solids, ratio, anthocyanins and decay incidence. The results for the chemical features showed statistical differences ( $p>0.05$ ) except for the $\mathrm{pH}$ value at the end of the storage. There were differences between crop for all parameters. During the storage period, the anthocyanin content increased on the 2008 crop and reduced on the fruits of 2009. To reduce the decay incidence it is recommended to use the coating with kefir grains. These fruits can be consumed until the third day of storage at $10{ }^{\circ} \mathrm{C}$.
\end{abstract}

Key words: Blackberry. Cassava starch. Water kefir. Fruits. Conservation.

\begin{abstract}
RESUMO - A amora preta é um fruto que vem se destacando por apresentar compostos bioativos em sua composição, no entanto, a sua estrutura frágil reduz o seu consumo in natura. O objetivo deste trabalho foi avaliar a qualidade físico-química dos frutos de amora-preta, cv. Tupy, produzidas em sistema orgânico, e recobertos com emulsões a base de fécula de mandioca e grãos de kefir de água, armazenadas sob refrigeração. Os frutos foram separados em três tratamentos, sendo um controle (T1) e dois tratamentos com revestimentos. Os revestimentos usados foram: solução de fécula de mandioca a 2,5\% (T2) e grãos de kefir de água a 20\% (T3). Os frutos dos três tratamentos foram armazenados a $10 \pm 2{ }^{\circ} \mathrm{C}$ e UR $85 \pm 3 \%$, sendo avaliados a cada 3 dias por um período de 12 dias. Determinou-se: perda de massa, firmeza, $\mathrm{pH}$, acidez total, sólidos solúveis, ratio, antocianinas e incidência de podridões. Os resultados obtidos para as características químicas apresentaram diferenças estatísticas a nível (p>0,05), exceto o valor de $\mathrm{pH}$ ao final do armazenamento. Observou-se diferenças entre safras para todos os parâmetros. Os teores de antocianinas durante o período de armazenamento aumentaram na safra de 2008 e diminuíram nos frutos de 2009. Para redução da incidência de podridões recomenda-se a utilização do revestimento com grãos de kefir, e esses frutos podem ser consumidos até o terceiro dia de conservação à $10{ }^{\circ} \mathrm{C}$.
\end{abstract}

Palavras-chave: Amora. Fécula de mandioca. Kefir de água. Frutas. Conservação.

\footnotetext{
*Autor para correspondência

${ }^{1}$ Recebido para publicação em 22/12/2010; aprovado em 01/11/2012

Parte da Dissertação de Mestrado em Agronomia do primeiro autor, com concessão de bolsa de estudo cedida pelo CNPq

${ }^{2}$ Laboratório de Bioquímica de Alimentos, Centro de Ciências Agrárias, Universidade Estadual de Maringá, Programa de Pós-Graduação em Agronomia,

Maringá-PR, Brasil, dalany5@yahoo.com.br, cassialourenzi@gmail.com,angelak.k@gmail.com

${ }^{3}$ Departamento de Química, Centro de Ciências Exatas, Universidade Estadual de Maringá, Maringá-PR, Brasil, eclemente@uem.br
} 


\section{INTRODUCTION}

The production of temperate climate fruit tree species in Brazil is still insufficient to meet domestic market demands, a situation that provides opportunities for the production of these fresh industrialized fruits in the country (CIA et al., 2007). Among the various fruit species with good prospects for cultivation and marketing, the blackberry is one of the most promising species, with significant growth in farmland in recent years (ANTUNES, 2002). Some signs have been observed, that show a change in eating habits among Brazilians towards a greater demand for organic products. Taking into account the presence of organic products on the supermarket shelves, it is estimated that there is a potential market of significant magnitude for these products (BORGUINI; TORRES, 2006).

So as to promote the technological, economic, environmental and social development introduced in the production of organic fruits, it is necessary to use different postharvest treatments, which may be associated with this production, trying to achieve a reduction of losses and maintain product quality by a longer period (CAMPOS; RODOVALHO; CLEMENTE, 2009). Among the methods of postharvest preservation, coatings and toppings are used on fruits in order to extend their preservation associated or not with the use of low temperatures. Temperature is probably the most important factor that affects the storage period of fruits and vegetables, because it regulates the rates of all physiological and biochemical processes (SANTOS et al., 2008).

Cassava starch can be used in fruit conservation after the gelation process, which occurs above $70{ }^{\circ} \mathrm{C}$ with water excess. Kefir grains look like white or slightly yellowish, gelatinous masses composed of protein and polysaccharide, which contain bacteria and yeasts involved in fermentation and they are recovered and reused for the next incubation. Ten yeasts species were identified in kefir and the main are, Isaatchenkia orientallis, Saccharomyces unisporos, S. exiguus and $S$. humaticus (LATORRE-GARCIA; CASTILHO-AGUDO; POLAINA, 2007). The use of water kefir has been spread by people who use it and pass the information on to the others. As these products are handmade and still little known, there is little research on their application.

Organic products are usually sold in packages, such as Styrofoam trays, plastic bags and films, however new biodegradable materials are being researched. The packages are aimed to differentiate the product, as well as to reduce its exposure to contamination by handling and / or contact with other non-organic products (ORMOND et al., 2002).

The blackberry is a fruit that has a short post harvest shelf-life, it also has fragile structure and high respiratory activity, for these reasons it requires technologies and studies to improve the longer shelf life and postharvest quality. The aim of this study was to evaluate the physical and chemical quality of cv. Tupy blackberry, produced in an organic system, and coated with emulsion based on cassava starch and water kefir grains, stored under refrigeration.

\section{MATERIAL AND METHODS}

The Tupy cultivar blackberry was produced in an organic system in the city of Palmas - PR. The fruits were harvested in December 2008 and also in December 2009 , in the morning, they were packed in 500g PET (polyethylene terephthalate) plastic containers, cooled and packed in Styrofoam boxes and sent to the Food Biochemistry Laboratory where the experiment was carried out. The fruits were selected according to the ripening (100\% of the surface with black color) and sanitized with sodium hypochlorite $2.0 \%$.

The fruits were divided into three groups, with one control treatment (T1) and two treatments with coatings. The coatings used were cassava starch solution $2.5 \%$ (T2) and water kefir grains at $20 \%$ (T3). The T2 coating was obtained from $50 \mathrm{~g}$ of cassava starch to $2 \mathrm{~L}$ of distilled water. The mixture was heated at $70{ }^{\circ} \mathrm{C}$ with constant stirring until gelation (20-30 min) of the solution, after thermal equilibrium at room temperature (CAMPOS; RODOVALHO; CLEMENTE, 2009); it was added $10 \mathrm{~mL}$ of glycerol and $10 \mathrm{~g}$ of sorbitol indicated by Kester and Fennema (1986), by shaking with the help of an ultrasonic mixer for 2 minutes. After the preparation of this solution, analysis of soluble solids (SS) and the coating $\mathrm{pH}$ were performed, this showed the SS content of $3.13^{\circ}$ Brix and $\mathrm{pH}$ of 6.79 . The T3 coating was prepared from $400 \mathrm{~g}$ of water kefir grains drained from the liquid and disintegrated with ultrasonic mixer. Next, 1.5 L of distilled water was added, keeping it under heating at $50{ }^{\circ} \mathrm{C}$ for 30 minutes under low speed, after thermal equilibrium at room temperature. It was added $10 \mathrm{~mL}$ of glycerol and $10 \mathrm{~g}$ of sorbitol indicated by Kester and Fennema (1986), completing the volume to $2 \mathrm{~L}$ and it was stirred with ultrasonic mixer for 2 minutes. The T3 solution showed SS content of $1.67{ }^{\circ}$ Brix and $\mathrm{pH}$ 4.24. The fruits were immersed in the coatings for 2 minutes, and then they were placed on nylon sieve screens to dry. Afterwards, $250 \mathrm{~g}$ of blackberry was weighed and packed in PET (polyethylene terephthalate) transparent plastic containers $(190 \mathrm{~cm} \times 120 \mathrm{~cm} \times 63 \mathrm{~cm})$, without perforations and with a lid and stored in cold chamber at $10 \pm 2{ }^{\circ} \mathrm{C}$ and $85 \pm 3 \% \mathrm{RH}$, simulating the storage condition of markets.

The experimental design used was completely randomized in a $3 \times 5 \times 2$ factorial design. Three treatments 
of the two harvests, December 2008 and 2009 were evaluated at $0 ; 3 ; 6 ; 9 ; 12$ days of refrigerated storage $\left(10 \pm 2{ }^{\circ} \mathrm{C}\right)$. The experimental unit of each treatment was made with $250 \mathrm{~g}$ of fruit, and the analysis was performed in four replicates.

Mass loss was analyzed, using semi-analytical balance (Bel Engineering, Mark 2200), and the results were expressed in percentage according to equation (1).

Weight loss $(\%)=\frac{(\text { initial weight }- \text { final weight })}{\text { initial weight }} \times 100(1)$

Firmness was measured using a compression test with the aid of a texture analyzer (Stable Micro Systems, TAXT.plus model). It was used a cylindrical SMSP/36R probe, $36 \mathrm{~mm}$ in diameter which compressed the fruit up to $40 \%$ of its height at a speed of $1.5 \mathrm{~mm} / \mathrm{s}$. 10 fruits of each treatment were analyzed during the storage period.

For chemical analysis fruits were ground in ultra mixer (Britânia) for 2 minutes and a nylon sieve was used to separate the seeds.

The $\mathrm{pH}$ was determined by a digital potentiometer (Hanna Instruments, model $\mathrm{pH} 300$ ), total acidity by titration, soluble solids (SS) using a digital refractometer (Atago, model Pocket pal-1) with a scale from 0 to $35^{\circ} \mathrm{Brix}$ and the ratio by SS/TA (CARVALHO et al., 1990).

Quantification of anthocyanins was performed using methods of Lees and Francis (LEES; FRANCIS, 1972), with modifications. The solvent used was $70 \%$ ethanol acidified to $\mathrm{pH} 2.0$ with $\mathrm{HCl}$. The fruits were crushed in the ultra mixer (Britânia) with $70 \%$ ethanol and left to rest for a night in the dark under refrigeration at $4{ }^{\circ} \mathrm{C}$. The extract was filtered and it was used a $2 \mathrm{~mL}$ aliquot in a $100 \mathrm{~mL}$ flask. The volume was completed with $70 \%$ ethanol and left to rest for 2 hours in the dark. After this period, readings of the absorbance were made in spectrophotometry at $\lambda=532 \mathrm{~nm}$.
The decay incidence was determined from the percentage of damaged fruits with $20 \%$ decay in its surface.

Data were statistically evaluated by variance analysis (ANOVA) and the Tukey test ( $\mathrm{p}>0.05$ ) was applied between averages using the SAS statistical software (SAS INSTITUTE, 2001) and regression analysis, to evaluate mass loss, decay incidence and firmness.

\section{RESULTS AND DISCUSSION}

The values of $\mathrm{pH}, \mathrm{TA}, \mathrm{SS}$, ratio (SS/TA), and anthocyanins of blackberries stored under refrigeration $\left(10 \pm 2{ }^{\circ} \mathrm{C}\right)$ with coatings are shown in Table $1 ; 2 ; 3 ; 4$ and 5 . During the storage period, observed that time had influence on physical-chemical compounds evaluated in this study.

The $\mathrm{pH}$ values (Tabela 1 ) at the beginning of the experiment of the two years, differ significantly; however, by the end of storage they had no differences ( $p>0.05)$. The fruits of the 2008 crop showed lower $\mathrm{pH}$ values compared to the 2009 crop. During the storage, the 2008 crop showed the highest increase in $\mathrm{pH}$, except the T3, that this fact was verified on the fruits harvested in 2009.

In Brazos and Comanche cultivars, Antunes, Duarte Filho and Souza (2003) report values of the beginning of their experiment in which they observed $\mathrm{pH}$ averages of 3.59 and 3.39 and at the end of storage time (12 days) the averages increased to 3.94 and 4.09, respectively. This increase in $\mathrm{pH}$ reported by this author was also observed in this study for all treatments in the two harvests. The $\mathrm{pH}$ is a parameter that measures the acidity of fruits and foods, and its increase is directly related to a decrease in acidity occurred with fruit maturity (CHITARRA; CHITARRA, 2005).

Tosun, Ustun e Tekguler (2008), studying the $\mathrm{pH}$ behavior during blackberry ripening, observed

Table 1 - $\mathrm{pH}$ averages in the fruit of blackberry cv. Tupy stored at $10 \pm 2{ }^{\circ} \mathrm{C}$ e $85 \pm 3 \% \mathrm{RH}$

\begin{tabular}{|c|c|c|c|c|c|c|}
\hline \multirow{2}{*}{ Period } & \multicolumn{2}{|c|}{--------------------T1* } & \multicolumn{2}{|c|}{-----------------T2*------------------ } & \multicolumn{2}{|c|}{------------------T3* } \\
\hline & 2008 & 2009 & 2008 & 2009 & 2008 & 2009 \\
\hline 0 day $\pm \delta \ddagger$ & $2.83 \mathrm{eE}^{* *} \pm 0.00$ & $3.07 \mathrm{aB} \pm 0.03$ & $2.90 \mathrm{dC} \pm 0.00$ & $3.02 \mathrm{bB} \pm 0.02$ & $2.95 \mathrm{cC} \pm 0.01$ & $3.01 \mathrm{bE} \pm 0.01$ \\
\hline 3 days $\pm \delta$ & $2.99 \mathrm{bD} \pm 0.06$ & $3.02 \mathrm{abB} \pm 0.02$ & $2.85 \mathrm{cC} \pm 0,02$ & $3.08 \mathrm{aB} \pm 0.01$ & $2.87 \mathrm{cC} \pm 0.02$ & $3.08 \mathrm{aD} \pm 0.05$ \\
\hline 6 days $\pm \delta$ & $3.08 \mathrm{bC} \pm 0.03$ & $3.30 \mathrm{aA} \pm 0.05$ & $3.04 \mathrm{bB} \pm 0.08$ & $3.27 \mathrm{aA} \pm 0.02$ & $3.27 \mathrm{aAB} \pm 0.03$ & $3.32 \mathrm{aC} \pm 0.03$ \\
\hline 9 days $\pm \delta$ & $3.27 \mathrm{bcB} \pm 0.02$ & $3.33 \mathrm{abA} \pm 0.02$ & $3.14 \mathrm{~dB} \pm 0.1$ & $3.33 \mathrm{abA} \pm 0.06$ & $3.18 \mathrm{cdB} \pm 0.03$ & $3.44 \mathrm{aB} \pm 0.02$ \\
\hline 12 days $\pm \delta$ & $3.53 \mathrm{aA} \pm 0.06$ & $3.39 \mathrm{aA} \pm 0.03$ & $3.49 \mathrm{aA} \pm 0.05$ & $3.38 \mathrm{aA} \pm 0.08$ & $3.37 \mathrm{aA} \pm 0.14$ & $3.52 \mathrm{aA} \pm 0.06$ \\
\hline
\end{tabular}

*Treatments: T1 - Uncoated T2 - Cassava starch 2.5\%, T3 - Water kefir Grains 20\%; **Averages followed by the same letter, lower case on the line and uppercase in column, did not differ by Tukey test $(\mathrm{p}>0.05)$; $\ddagger$ standard deviation 
averages of 2.64 in red fruits and 3.14 in ripe fruits. The results observed in this study to the ripe fruit of cv. Tupy were similar to that observed by Tosun, Ustun and Tekguler (2008) in which there was an increase in $\mathrm{pH}$ during storage.

Measurements of TA contents (Tabela 2) showed significant differences during refrigerated storage in both estimated years.
The TA and SS values were reduced at the end of the storage period for all treatments. Among the crops analyzed, the fruits of 2008 presented lower acidity, this fact corroborates with the results presented for the SS contents of these fruits, which presented higher SS percentages than the 2009 crop.

Sousa (2007) reports that the reduced levels of TA and SS during the postharvest storage occur because the

Table 2 - Titratable Acid averages - TA ( $\mathrm{g}$ citric acid $100 \mathrm{~g}^{-1}$ ) in the fruits of blackberry cv. Tupy stored at $10 \pm 2{ }^{\circ} \mathrm{C}$ e $85 \pm 3 \% \mathrm{RH}$

\begin{tabular}{|c|c|c|c|c|c|c|}
\hline \multirow[b]{2}{*}{ erioc } & \multicolumn{2}{|c|}{ 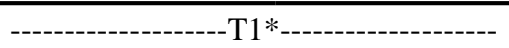 } & \multicolumn{2}{|c|}{ 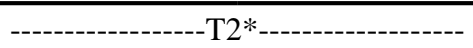 } & \multicolumn{2}{|c|}{ 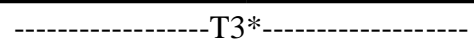 } \\
\hline & 8 & 2009 & 2008 & 2009 & 2008 & 2009 \\
\hline & $1.00 \mathrm{CCD}=$ & $20 \mathrm{~s}$ & 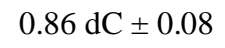 & & 02 & 4 \\
\hline 3 & $1.31 \mathrm{aA} \pm 0.07$ & $1.01 \mathrm{bB} \pm 0.08$ & $1.23 \mathrm{aA} \pm 0.06$ & $1.06 \mathrm{bB} \pm 0$ & $1.23 \mathrm{aA} \pm 0.04$ & 1. \\
\hline & & & & 8 & & .08 \\
\hline $9 \mathrm{da}$ & $95 \mathrm{abcD} \pm 0.12$ & .05 & $\mathrm{~B} \pm 0.04$ & 4 & 0.6 & 0.87 \\
\hline 12 days $\pm \delta$ & $0.88 \mathrm{bcBC} \pm 0.03$ & $0.90 \mathrm{bcC} \pm 0.07$ & $0.85 \mathrm{cB} \pm 0.05$ & $1.12 \mathrm{aB} \pm 0.09$ & $0.88 \mathrm{cBC} \pm 0.16$ & $1.03 \mathrm{bB} \pm 0.09$ \\
\hline
\end{tabular}

*Treatments: T1 - Uncoated T2 - Cassava starch 2.5\%, T3 - Water kefir Grains 20\%; **Averages followed by the same letter, lower case on the line and uppercase in column, did not differ by Tukey test ( $>0.05)$; $\ddagger$ standard deviation

Table 3 - Soluble Solids averages - SS $\left({ }^{\circ}\right.$ Brix) in blackberry fruits cv. Tupy stored at $10 \pm 2{ }^{\circ} \mathrm{Ce} 85 \pm 3 \% \mathrm{RH}$

\begin{tabular}{|c|c|c|c|c|c|c|}
\hline \multirow{2}{*}{ eriod } & \multicolumn{2}{|c|}{---------------------'T1*-------------------- } & \multicolumn{2}{|c|}{------------------T2*----------------- } & \multicolumn{2}{|c|}{--------------------T3*------------------- } \\
\hline & & 2000 & 2008 & 2009 & 2008 & 20 \\
\hline & -0.00 & (.JJ & 0 & ( & & \\
\hline & $=0.7$ & 7.4 & & 7.5 & & 7.6 \\
\hline 6 & 7 & 7.7 & 4 & 7 & 9. & 7. \\
\hline $9 \mathrm{c}$ & $8.90 \mathrm{a}$ & 7. & 8 & 6 & 8.3 & 7.33 \\
\hline 12 days $\pm \delta$ & $8.43 \mathrm{aC} \pm 0.29$ & $6.68 \mathrm{bC} \pm 0.41$ & $8.50 \mathrm{aB} \pm 0.26$ & $6.08 \mathrm{bcD} \pm 0.26$ & $8.63 \mathrm{aBC} \pm 0.25$ & $5.80 \mathrm{cC} \pm 0.31$ \\
\hline
\end{tabular}

*Treatments: T1 - Uncoated T2 - Cassava starch 2.5\%, T3 - Water kefir Grains 20\%; **Averages followed by the same letter, lower case on the line and uppercase in column, did not differ by Tukey test ( $>0.05)$; $\ddagger$ standard deviation

Table 4 - Ratio averages (SS / TA) in blackberry fruits cv. Tupy stored at $10 \pm 2{ }^{\circ} \mathrm{C}$ e $85 \pm 3 \% \mathrm{RH}$

\begin{tabular}{|c|c|c|c|c|c|c|}
\hline \multirow{2}{*}{ Period } & \multicolumn{2}{|c|}{----------------------T1*-------------------- } & \multicolumn{2}{|c|}{-------------------T2*------------------ } & \multicolumn{2}{|c|}{----------------------T3*-------------------- } \\
\hline & 2008 & 2009 & 2008 & 2009 & 2008 & 2009 \\
\hline 0 day $\pm \delta \ddagger$ & $9.64 \mathrm{cA}^{* *} \pm 0.23$ & $6.85 \mathrm{deB} \pm 0.38$ & $10.72 \mathrm{bA} \pm 0.52$ & $6.28 \mathrm{eB} \pm 0.27$ & $12.46 \mathrm{aA} \pm 0.40$ & $7.05 \mathrm{~dB} \pm 0.12$ \\
\hline 3 days $\pm \delta$ & $6.80 \mathrm{aC} \pm 0.84$ & $7.32 \mathrm{aB} \pm 0.77$ & $7.49 \mathrm{aB} \pm 0.2$ & $7.08 \mathrm{aA} \pm 0.13$ & $7.41 \mathrm{aD} \pm 0.37$ & $7.56 \mathrm{aB} \pm 0.55$ \\
\hline 6 days $\pm \delta$ & $7.94 \mathrm{abcBC} \pm 0.16$ & $9.28 \mathrm{aA} \pm 0.4$ & $8.85 \mathrm{bcB} \pm 0.49$ & $7.62 \mathrm{cA} \pm 0.6$ & $9.23 \mathrm{abCD} \pm 1.0$ & $8.31 \mathrm{abcA} \pm 0.73$ \\
\hline 9 days $\pm \delta$ & $9.35 \mathrm{bAB} \pm 1.09$ & $8.51 \mathrm{bA} \pm 0.96$ & $8.63 \mathrm{bB} \pm 0.72$ & $6.49 \mathrm{cB} \pm 0.65$ & $11.93 \mathrm{aAB} \pm 0.7$ & $8.36 \mathrm{bA} \pm 0.29$ \\
\hline 12 days $\pm \delta$ & $9.55 \mathrm{abA} \pm 0.7$ & $7.47 \mathrm{bcB} \pm 0.91$ & $10.10 \mathrm{aA} \pm 0.91$ & $5.47 \mathrm{cC} \pm 0.67$ & $10.05 \mathrm{aBC} \pm 2.29$ & $5.63 \mathrm{cC} \pm 0.33$ \\
\hline
\end{tabular}

*Treatments: T1 - Uncoated, T2 - Cassava starch 2.5\%, T3 - Water kefir Grains 20\%; **Averages followed by the same letter, lower case on the line and uppercase in column, did not differ by Tukey test $(\mathrm{p}>0.05) ; \ddagger$ standard deviation 
sugars and acids are used as respiratory substrates, reducing their reserves. The author analyzed the postharvest behavior of berries, cv. Arapaho, harvested at the beginning and end of June and the SS values were 13.0 and $11.0{ }^{\circ}$ Brix, respectively. Meneghel, Benassi and Yamashita. (2008) studied the application of coatings with sodium alginate and had average values for SS 9.1, 8.4 and $8.1^{\circ}$ Brix. Antunes et al. (2003) noticed a reduction in the SS levels for fruits Brazos and Comanche cv., during storage at $20{ }^{\circ} \mathrm{C}$.

Statistical difference between averages $(\mathrm{p}>0.05)$ was observed for the ratio (Tabela 4) and T3 treatment showed higher ratio.

The SS/TA ratio is used to evaluate the fruit sweetsour balance. According to Carvalho et al. (1990) when this ratio is in the range of 12 to 18 , it indicates a balance sensory equilibrium. At time zero storage, T3 showed values within this range of ratio. However, the fruits of the 2008 crop presented higher SS/TA ratio, showing that these fruits have a better maturity balance.

Acosta-Montoya et al. (2010) evaluated the maturity index (Brix/ acidity), showed also to be a good indicator of fruit maturity as it increased during ripening as the fruits when became darker, less red and bluer.

In Table 5 it is possible to observe a variation in anthocyanin content during the experiment. A reduction in anthocyanins occurred in the fruit harvested in 2009. It is observed that the loss of mass and the decay incidence on the fruits of 2008 crop were lower until the third day of storage.

Anthocyanins (glycosides and acylglycosides of anthocyanidins) are important in the food industry, being regarded as potential replacements for synthetic food colourants, and in human nutrition, as protecting agent against some diseases (WU; PRIOR, 2005).

Meneghel, Benassi and Yamashita (2008) had initial values of anthocyanins of $53 \mathrm{mg} 100 \mathrm{~g}^{-1}$ in fruits of the Comanche cultivar and observed a linear increase in these levels throughout the storage period. This study also observed increased levels of anthocyanins during the retention period; T3 had the highest level at the end of storage, compared to other treatments. Several factors may contribute to the degradation of anthocyanins, such as sugars (especially fructose) that accelerate the darkening process, besides the $\mathrm{pH}$ that, being between 1 and 3.5 gives a greater stability (ARAÚJO, 2006).

There may be differences in the behavior of the chemical characteristics analyzed between two harvests, and these conditions can be justified by factors prior to harvesting, ie, climatic conditions and fruits harvest stage (PINHEIRO; VILAS-BOAS; MESQUITA, 2005).

The percentage of weight loss can be seen in Figures 1A and B and decay incidence in Figures $1 \mathrm{C}$ and D. Averages for the weight loss had increased during the storage period for all treatments.

Decay incidence increased during the period of 12 days of refrigerated storage, the highest percentage achieved by the ninth day of storage was for $\mathrm{T} 2$.

Antunes, Duarte Filho and Souza (2003) evaluated the use of polyvinyl chloride (PVC) film in cv. Brazos and Comanche and observed losses of $14.86 \%$ at temperatures $20{ }^{\circ} \mathrm{C}$. In this work the treatment of lower efficiency was $\mathrm{T} 2$ and the one which better reduced the mass loss until the 6th day of storage was T3.

Cia et al. (2007) in studies with cv. Grarani and Caingangue had losses of 24 and 19\% respectively in 3 days of storage at room conditions. In Navaho cv. fruits stored for seven days, followed by two days at $20{ }^{\circ} \mathrm{C}$, the decay incidence was 14\% (PERKINS-VEAZIE et al., 1997). The differences between the two harvests for the mass loss and decay incidence values may be justified by climatic

Table 5 - Total anthocyanins averages $\left(\mathrm{mg}^{100 \mathrm{~g}^{-1)}}\right.$ in blackberry fruits cv. Tupy stored at $10 \pm 2{ }^{\circ} \mathrm{C}$ e $85 \pm 3 \% \mathrm{RH}$

\begin{tabular}{|c|c|c|c|c|c|c|}
\hline \multirow{2}{*}{ erio } & \multicolumn{2}{|c|}{ 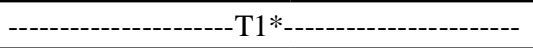 } & \multicolumn{2}{|c|}{ 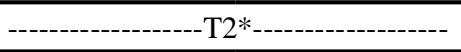 } & \multicolumn{2}{|c|}{-----------------T3* } \\
\hline & 200 & 2009 & 2008 & 2009 & 2008 & 2009 \\
\hline & 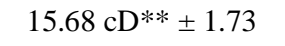 & (1) & $15.21 \mathrm{cD} \pm 0.03$ & 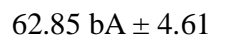 & 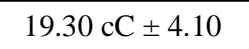 & \\
\hline & 8 & & 5 & 0 & 01 & 27 \\
\hline & $67 \mathrm{r}$ & $70.01 \mathrm{bcA} \pm 5.25$ & \pm & 4 & 1 & 2 \\
\hline & $28.44 \mathrm{aA} \pm 6.35$ & 771 & $25.84 \mathrm{aA} \pm 2.09$ & $54.19 \mathrm{bB} \pm 3.64$ & $117.0 \mathrm{aA} \pm 13.54$ & $61.13 \mathrm{~b}$ \\
\hline 12 days $\pm \delta$ & $108.97 \mathrm{abAB} \pm 11.82$ & $52.04 \mathrm{cB} \pm 10.48$ & $85.88 \mathrm{bB} \pm 18.83$ & $46.44 \mathrm{cB} \pm 6.81$ & $120.04 \mathrm{aA} \pm 16.56$ & $38.66 \mathrm{cC} \pm 3.73$ \\
\hline
\end{tabular}

*Treatments: T1 - Uncoated, T2 - Cassava starch 2.5\%, T3 - Water kefir Grains 20\%; **Averages followed by the same letter, lower case on the line and uppercase in column, did not differ by Tukey test $(\mathrm{p}>0.05) ; \ddagger$ standard deviation 
Figure 1 - Weight loss (A - 2008; B-2009) and decay incidence (C - 2008; D -2009) in organic blackberries, cv. Tupy, with biodegradable coatings, stored under refrigeration $\left(10 \pm 2{ }^{\circ} \mathrm{C}\right.$ e $\left.85 \pm 3 \% \mathrm{RH}\right)$
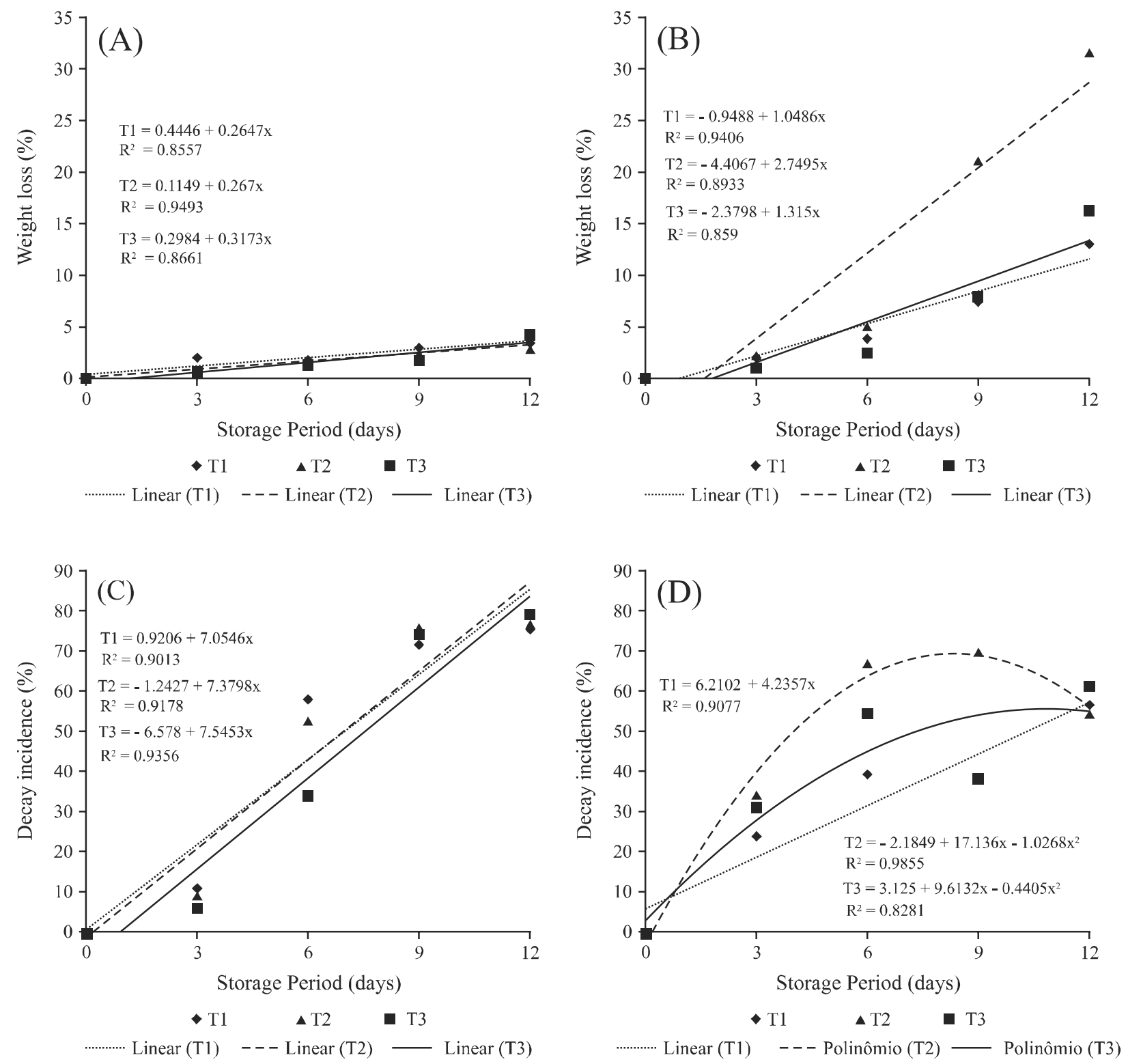

conditions arising in each year, or due to their fragile postharvest handling from the field to storage, which can cause cracks and thus raise the losses.

Figure 2 shows the average firmness of the fruits analyzed. It is observed that the average values decreased during storage, for both years. Blackberries coated with $\mathrm{T} 2$ and $\mathrm{T} 3$ showed the best firmness until the sixth day of storage. the fruits harvested in 2008 showed higher firmness for the initially of storage period, and after the third day of storage the firmness values showed similar behavior in all fruits (2008 and 2009 crops).

The firmness is a factor that directly influences the quality and postharvest life. Meneghel, Benassi and Yamashita(2008) evaluated three types of coatings in blackberries stored at $0{ }^{\circ} \mathrm{C}$ and observed that the firmness of these fruits was not reduced with storage time and was not affected by the presence of coatings, the averages were 16; 20 and $19 \mathrm{~N}$. This was not observed in this study where the fruits stored at $10{ }^{\circ} \mathrm{C}$ had the firmness reduced. In a work done by Sousa (2007) in blackberries harvested at the beginning and end of June, it was found that the firmness of these fruit had a slight wobble $(3.5$ and $4.20 \mathrm{~N})$ until the ninth 
Figure 2 - Firmness (A - 2008; B - 2009) during refrigerated storage of organic blackberries, cv. Tupy, with biodegradable coatings, stored under refrigeration $\left(10 \pm 2{ }^{\circ} \mathrm{C}\right.$ e $\left.85 \pm 3 \% \mathrm{RH}\right)$

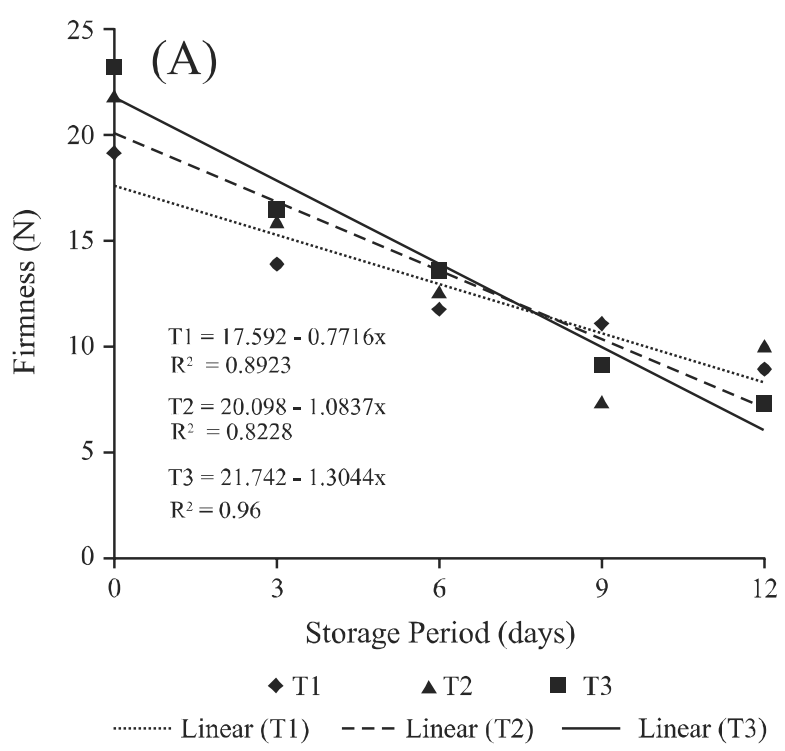

day. The fruits of this work with cv. Tupy showed higher firmness than those found by this author in which by the end of the 12th day of storage the firmness of T2 treatment showed the lowest resistance, T2 and T3 interfered positively until the sixth day for the two harvests.

\section{CONCLUSION}

To reduce the decay incidence, the use of the coating with kefir grains is recommended. This coating also has a smaller weight loss and increased fruit firmness and chemical quality, being able to be consumed until the $3 \mathrm{rd}$ day of storage at $10^{\circ} \mathrm{C}$.

\section{ACKNOWLEDGEMENTS}

This study had the support of the Conselho Nacional de Desenvolvimento Científico e Tecnológico (CNPq).

\section{REFERENCES}

ACOSTA-MONTOYA, Ó. et al. Phenolic content and antioxidant capacity of tropical highland blackberry (Rubus adenotrichus Schltdl.) during three edible maturity stages. Food Chemistry, v. 119 , n. 4 , p. 1497-1501, 2010.

ANTUNES, L. E. C. Amora-preta: nova opção de cultivo no Brasil. Ciência Rural, v. 32, n. 1, p. 151-158, 2002.

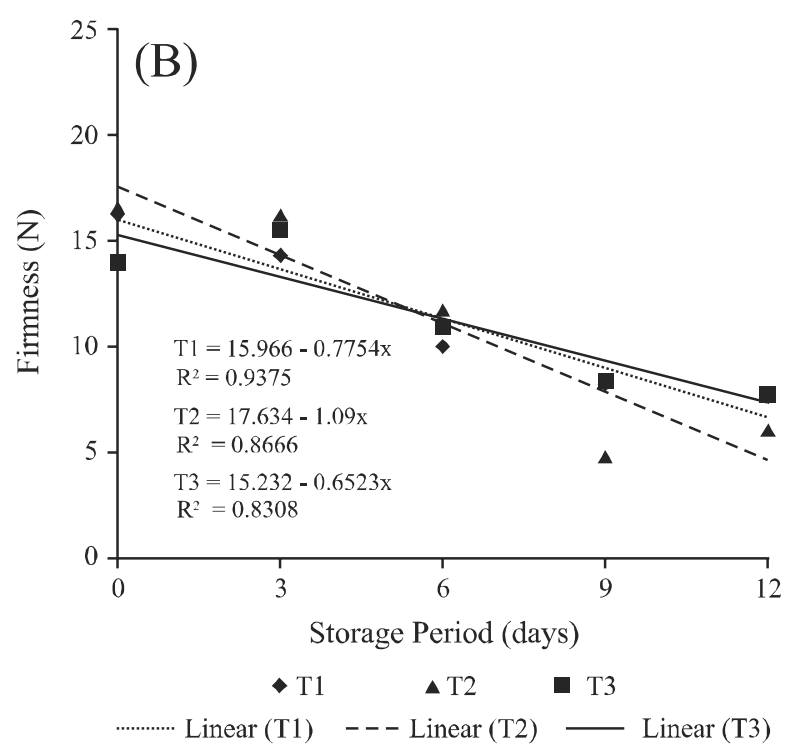

ANTUNES, L. E. C.; DUARTE-FILHO, J.; SOUZA, C. M. Conservação pós-colheita de frutos de amoreira-preta. Pesquisa Agropecuária Brasileira, v. 38, n. 3, p. 413-419, 2003.

ARAÚJO, J. M. A. Química de alimentos: teoria e prática. 3rd ed. Lavras: UFV, 2006. 478 p.

BORGUINI, R. G.; TORRES, E. A. F. S. Alimentos orgânicos: qualidade nutritiva e segurança do alimento. Segurança Alimentar e Nutricional, v. 13, n. 2, p. 64-75, 2006.

CAMPOS, R. P.; RODOVALHO, M. A.; CLEMENTE, E. Coating on 'Camarosa' organic strawberries stored at low temperature. Brazilian Journal Food Technology, v. 12, n. 1, p.60-67, 2009.

CARVALHO, C. R. L. et al. Análises químicas de alimentos. Campinas: Instituto de Tecnologia de Alimentos, 1990. 121 p.

CHITARRA, M. I.; CHITARRA, A. B. Pós-colheita de frutas e hortaliças: fisiologia e manuseio. 2nd ed. revisada e ampliada. Lavras: Universidade Federal de Lavras, 2005. 785 p.

CIA, P. et al. Atmosfera modificada e refrigeração para conservação pós-colheita da amora-preta. Bioscience Journal, v. 23, n. 3, p. 11-16, 2007.

KESTER, J. J.; FENNEMA, O. R. Edible films and coatings: a review. Food Technology, v. 40, n. 12, p. 47-59, 1986.

LATORRE-GARCÍA, L.; CASTILLO-AGUDO, L.; POLAINA, J. Taxonomical classification of yeasts isolated from kefir base don the sequence of their ribosomal RNA genes. World Journal Microbiology Biotechnology, v. 23, n. 11, p. 785-791, 2007.

LEES, D. H.; FRANCIS, F. J. Stamdardization of pigment analyses in cranberries. Horticuture Scince, v. 7, n. 1, p. 83-84, 1972. 
MENEGHEL, R. F. A.; BENASSI, M. T.; YAMASHITA, F. Revestimento comestível de alginato de sódio para frutos de amora-preta (Rubus ulmifolius). Semina: Ciências Agrárias, v. 29, n. 3, p. 609-618, 2008.

ORMOND, J. G. P. et al. Agricultura orgânica: quando o passado é futuro. 2002.p. 3-34. Disponível em: <http://www.bndes.gov. br/SiteBNDES/export/sites/default/bndes_pt/Galerias/ Arquivos/ conhecimento/bnset/set1501.pdf> . Acesso em: 10 abr. 2012.

PERKINS-VEAZIE, P. et al. Air shipment of 'Navaho' blackberry fruit to Europe is feasible. HortScience, v. 32, n. 1 p. 132, 1997.

PINHEIRO, A. M. P.; VILAS BOAS, E. V. B.; MESQUITA, C. T. Ação do 1-metilciclopropeno (1-MCP) na vida de prateleira da banana 'Maçã'. Revista Brasileira de Fruticultura, v. 27, n. 1, p. 25-28, 2005.
SANTOS, C. A. A. et al. Uso de quitosana e embalagem plástica na conservação pós-colheita de pêssegos 'Douradão'. Revista Brasileira de Fruticultura, v. 30, n. 1, p. 88-93, 2008.

SAS INSTITUTE. Statistical Analysis System. SAS User's Guide: 8.2. Cary: SAS Institute, 2001. 1 CD-ROM.

SOUSA, M. B. Amora: Qualidade pós-colheita. Brasília: Ministério da Agricultura Pecuária e Abastecimento - MAPA, 2007. Folhas de Divulgação AGRO 556.

TOSUN, I.; USTUN, N. S.; TEKGULER, B. Physical and chemical changes during ripening of blackberry fruits. Science Agricola, v. 65, n. 1, p. 87-90, 2008.

WU,X.;PRIOR,R.L.Systematicidentificationandcharacterization of anthocyanins by HPLC-ESI-MS/MS in common foods in the United States: fruits and berries. Journal of Agricultural and Food Chemistry, v. 53, n. 7, p. 2589-2599, 2005. 